\title{
IMPACT INDICATORS FOR STOCK MARKETS RETURN
}

\author{
Alina Kvietkauskien $\dot{e}^{1} \&$ Modestas Plakys $^{2}$
}

UDC / UDK: 336.76

JEL classification / JEL klasifikacija: G1

DOI: https://doi.org/10.22598/pi-be/2017.11.2.59

Review / Pregledni rad

Received / Primljeno: September 13, 2017 / 13. rujna 2017.

Accepted for publishing / Prihvaćeno za tisak: November 27, 2017 / 27. studenoga 2017.

\section{Summary}

The paper examines the influence of impact indicators on stock market returns. The authors analyse various theoretical and empirical studies in order to form a set of impact criteria for stock market selection. The different examinations aimed to identify the co-integrating relationship between stock market return and such impact indicators as money supply, exchange rate, short and long-term interest rates and others. It is often observed that stock prices tend to fluctuate with economic indicators that have positive and negative effects on stock market returns. A detailed analysis of the selected topic has shown that there is no unified or general method for the selection of the mentioned criteria; therefore, the authors propose a set of criteria that should be used for stock market selection in order to generate sustainable market return in the long term.

Key words: impact indicators, stock market return, market selection.

\section{INTRODUCTION}

The capital market is one of the most important elements of the economy, playing a significant role in economic welfare that fosters sustainable economic development and capital formation. The capital market mobilizes capital for the corporate sector, it proposes alternative investment possibilities for individuals and institutional investors in order to maximize their returns. The volume and return of all capital market transactions are affected not only by the issuers and investors, but also by the country's

\footnotetext{
1 Alina Kvietkauskienė, Ph.D., Lecturer, Faculty of Business Management, Vilnius Gediminas Technical University, Vilnius, Lithuania, E-mail: alina.kvietkauskiene@vgtu.lt

2 Modestas Plakys, Dr. of Economics, Head of Private Banking Department, Nordea Bank AB, Vilnius, Lithuania, E-mail: modestas.plakys@nordea.com
} 
economy. Hence, investors tend to evaluate the macroeconomic indicators that would increase the stock market return significantly. Abundant empirical studies have investigated the influences of macroeconomic indicators on companies' expected cash flows and stock returns. Bodie (1976), Fama (1981), Fama and Schwert (1977), Jaffe and Mandelker (1976); Nelson (1976), Siklos \& Kwok (1999) investigated the impact of the inflation rate on stock market return, Boyd et al (2001) examined the unemployment rate, Ang and Bekaert (2001) investigated interest rates, Campbell (1987), Fama and French (1989) examined long-term and bond yields differentials. Kang and Ratti (2013) focused greatly on oil price shocks and the uncertainty of economic policy. They argued that policy uncertainty had a significantly negative impact on stock market returns, while Hamilton (2009) and Killian (2009) suggested that different price shocks in the crude oil market have recognizable effects on the stock market. A large number of studies, conducted in various countries in the world, have revealed the relationship between macroeconomic indicators and the volatility of stock returns. Research findings have shown that, with slight fluctuations, these macroeconomic indicators have a significant effect on stock market returns. However, only a few studies have been carried out on the relationships between European stock market returns and macroeconomic indicators, and only a small part of these studies confirmed this relationship using market data.

The topic of this article are the impact criteria for stock market selection.

The main aim of the article is to provide a set of impact criteria for stock market selection, generating stable returns in the long term.

The main tasks of the article are:

- To analyze the works of researchers who investigated the impact of indicators on stock market returns;

- To propose the most adequate set of impact criteria for stock market selection based on the investigation, carried out by researchers, in order to define sustainable return in the long term.

It should be noted that the impact indicators are a set of macroeconomic, microeconomic and behavior indicators that have an influence on stock market return and will be analyzed in the article.

\section{A REVIEW OF THE RESEARCH ON THE INFLUENCE OF IMPACT INDICATORS ON STOCK MARKETS}

In order to generate sustainable return, it is important to develop a conceptual framework for stock market selection. A number of different studies shows that macroeconomic indicators affect stock market returns. It was theoretically established that stock returns change under certain conditions: their increase is noticed during economic contractions and a decrease during recoveries. The volatility in stock markets is affected by changes in macroeconomic indicators such as GDP, money supply, inflation, exchange rate and others, but there are no fully implemented methods that could be used for detailed stock market selection in order to ensure stable investment return. 
Therefore, authors try to collect different approaches in order to select the most important impact indicators.

Cagli et al. (2010) determined that the stock market is related to gross domestic product. Savry, Broyer (2002) argued that neither industrial production nor factory orders explain the development of overall German real activity; therefore, they use the quarterly GDP growth rates as an explained variable. However, Savry and Broyer (2002) came to the conclusion that sentiment indicators perform better in forecasting the manufacturing sector. The research carried out showed that a rise in GDP, indicating the growth of the American economy and making it more attractive to investors, strengthened the US dollar. Horobet and Dumitrescu (2009) verified the importance of the GDP growth rate on stock market returns. The most cited studies are Fama (1990) and Schwert (1990), which confirm that there is a positive relation between GDP and stock prices. The studies of other authors (Mohammad et al. (2009); Hussain et al. (2001)) have also confirmed that GDP positively influences stock prices. Dimson et al. (2016) studied the relationship between long-term stock market returns and long-term GDP growth. His studies showed that the best way for investors to see how performance changes over time is to examine the real GDP annual growth (yoy, \%). Changes in information about the future changes of real GDP affect fluctuations of stock market prices. Thus, changes in stock prices will reduce the asset structure of companies and affect the expenditure of their borrowing. When it costs more for companies to borrow money, they borrow and invest less and real GDP growth slows down. Changes in information about the future changes of real GDP may cause price changes in the stock market (Ray, 2012). The conclusion is that stock prices can be used as a forecasting tool for future economic activity but the actual causality is from future GDP growth to current stock prices (Ifionu \& Ibe, 2015).

The major part of the macroeconomic literature focuses on monetary factors as the prevalent indicators of stock market returns. Patelis (1997) analyses the role of monetary and financial indicators in predicting stock market returns. He finds that increases in the federal funds rate have a significant negative impact on predicted stock returns in the short term, but a positive one in the longer term. This predictability works largely through the effect of the federal funds rate changes on anticipated excess returns down the road, rather than dividends or expected returns. The event-study approach, used by Bernanke and Kuttner (2005), was based on observing daily changes on monetary policy decision dates to uncover the effect that unanticipated changes in the federal funds rate have on stock prices. The researchers found that a surprise 25 -basis-point cut in the federal funds rate is related with about a one percent increase in stock prices. The analysis largely attributes that response to persistent declines in the equity premium, and to a lesser extent to the relevant cash flows. They do not report, however, the dynamic response of stock prices to the monetary policy surprise, although there is a positive relationship between money supply and inflation.

According to Liu and Shrestha (2008), central bank interest rates or the government securities rate have a mixed impact on stock market returns. The interest rate as a variable was found to significantly affect stock returns by Maysami and Koh (2000), Papapetrou (2001), Akkum, Vuran (2003), Al-Sharkas (2004), Uddin, Alam (2007), Tür- 
soy et al. (2008) and Ullah et al. (2014). The mentioned authors determined a negative relationship between the interest rate and stock prices. The increase of rates in bank deposits leads to a situation in which people redirect their money from the capital market to the banks, which leads to a decline in the demand for stocks. However, the opposite situation will happen if the deposit rate decreases. Additionally, when the interest rate on deposits rises, the lending rate also rises, which will have a negative impact on investment, hence also on stock prices and vice versa (Barakat et al., 2016).

In this regard, Alam and Uddin (2009) investigated the interest rates of fifteen developed and developing countries during the period from 1988 to 2003. Using both time series and panel regressions, they claimed that for all fifteen countries stock prices were negatively related with interest rates. They also determined that interest rate changes had a significantly negative relationship with stock price changes, which appeared only in six countries out of fifteen (Masuduzzaman, 2012).

During financial crises and recessions, the stock markets tend to perform negatively and government debt levels seem to rise. Garcia and Liu (1999), Yartey (2008), Adrianaivo and Yartey (2009), Kemboi and Tarus (2012), Aigheyisi and Edore (2013), El-Nadar and Alraimony (2013) exclude external debt as a factor that affects the development of the stock exchange. The authors observe that the short-run effect of domestic debt, external debt and recurrent expenditure on the value of stock market transactions is of minor importance. This assumes a disconnect between domestic debt, external debt, government recurrent expenditure and stock market development in both the short and the long run. Capital expenditure is observed to have a significant negative short-run effect on stock market development. This indicates that an increase in government capital expenditure adversely affects the value of transactions on the stock market (Scott, Ovuefeyen 2014). The authors of the paper propose that the debt to GDP ratio be taken as a key indicator for stock market returns due to its positive relation with longterm stock market returns. Government debt levels are associated with higher future stock market returns.

The alternative indicator that can be used as a proxy to monetary policy rates are country 10-year government benchmark yields (\%). When the Federal Reserve wants interest rates to fall, it buys U.S. Treasuries. This is the same as increasing demand for the nation's bonds, which makes their values rise. As with all bonds, when the values rise, interest rates fall. This is why lower interest rates put upward pressure on stock prices. Bond buyers then get a lower interest rate, and therefore return, on their purchases. This forces them to consider buying higher-risk stocks to get a better return. As a result, low-interest rates boost economic growth. This leads to higher corporate earnings and higher stock prices. Of course, higher bond yields demonstrate the security and strong economy of the country.

Nevertheless, inflation and money supply have a dual effect on stock market returns. First of all, they have a positive effect with regard to a company's value. When money supply increases it automatically causes an increase in inflation and, likewise, in the expected rate of return. The use of a high expected rate of return decreases a company's profit and becomes a reason for lower share prices. Second, an increase in 
money supply and inflation affects the company's profit in a positive way with regard to dividends and stock prices. For these reasons, Patelis (1997) investigated the relationship between money supply, inflation and stock returns. Liu and Shrestha (2008) were of the same opinion about the existing co-integration between stock prices and the following macroeconomic indicators: inflation, exchange rate, money supply, industrial production and interest rates. Walter (1988) argued that monetary aggregates could be used to measure any nation's money stock. He also stated that further investigation should focus on phenomena such as the relationship between monetary measures and macroeconomic indicators such as the employment ratio, national income and interest rates in order to predict the changes in economic activities, inflation and interest rates. (Barakat et al., 2016).

Inflation, as a variable found to significantly affect stock returns, was investigated in many research works (Fama \& Schwert, 1977; Firth, 1979; Chen et al., 1986; Cohn \& Lessard, 1980; Fama, 1981; Gultekin, 1983; Kaul, 1986; Al-Sharkas, 2004; Adrangi et al. 2002; Akkum \& Vuran, 2003; Albeni \& Demir, 2005; Mutan \& Canakci, 2007; Kargi \& Terzi, 1999). Some of the research shows that there is no positive correlation between inflation and stock market returns. One of the authors, Buyuksalvarci (2010), argued that the inflation rate does not have any significant effect on stock market returns. Quite a few empirical studies (Flannery \& Protopapadakis, 2002; Thalassinos et al. 2006) have provided some evidence that inflation has a negative short-run effect on stock returns, while other studies (Masuduzzaman, 2012; Ullah et al., 2014) have reported a positive long-run Fisher effect on stock returns. According to Subeniotis et al. (2011), the coefficient of inflation is not statistically significant, and the negative sign can be explained by the short-run sample period. If inflation rises, companies will increase their profits while purchasing power falls. Indeed, some empirical studies have shown a negative short-run relationship between inflation and the stock market, although the relationship is positive in the long term, while there is no consensus as to the wealth effect of industrial production on the stock market.

Diaz and Jareno (2009) observed that inflation is positive when the inflation rate is higher than expected, which is economically bad news, as it implied a meaningful impact of stock returns on the Spanish stock market. Mittal and Pal (2011) reached a similar conclusion regarding the Indian stock return volatility. They examined the Indian stock market during the period of 1995-2008, using a VAR model, and demonstrated that the inflation rate has an observable effect in the major stock markets of India. Talla (2013) claimed that inflation has a dual effect on the stock market - positive and negative. He noted that both unexpected and expected inflation determines the direction of the relationship between stock market and inflation. Companies tend to increase their prices when demand exceeds supply. This would increase their earnings, which would lead to an increase in dividends paid resulting in increased demand for the company's stock and eventually increasing its stocks value (Barakat et al., 2016).

According to Coleman and Agyire-Tettey (2008), inflation affects investment decisions and savings through different channels. Generally speaking, unanticipated inflation distorts the planning horizon of economic units. It lowers the real interest rate, holding all other factors constant. Unstable inflationary dynamics heighten uncertain- 
ties regarding future prices and investment. Once there is a high degree of uncertainty in investment due to the pricing mechanism, people resort to investing in physical assets.

The Consumer Price Index (CPI) is used as a measure of inflation and Talla (2013) in his studies also used the Consumer Price Index as an alternative indicator for inflation. In normal economic conditions, an increase in CPI leads to a growth in interest rates, which in turn boosts the US dollar, as the higher rates make investment more attractive. Lakshmi and Tuwajri (2014) confirmed the importance of this indicator on stock market returns.

Generally speaking, most of the analysed works have shown that the connection between inflation and stock market returns exists. The most recent research also investigated the relationship between inflation and stock market returns (Kuwornu, 2012; Reddy, 2012; Barnor, 2014; Pinjaman \& Aralas, 2015). The authors propose to examine the effect of CPI for importance on stock market sustainable return in combination with other impact indicators so as to determine the relationship between various factors and stock market return.

Shanken and Weinstein (2006) concluded that the only significant factor for stock markets is the Index of Industrial Production. In their studies, Liu and Shrestha (2008) found that there is a co-integrating relationship between stock prices and industrial production. Flannery and Protopapadakis (2002) and Thalassinos et al. (2006) wrote about index importance for stock markets. The role of industrial production, as a variable in the determination of stock market prices remains an open question, since the results of a number of empirical studies do not conclusively determine a significant and reliable statistical relationship between them (Fama, 1981; Gultekin, 1983). Chen et al. (1986) establish the industrial production ratio as an essential risk factor for the determination of stock returns, while Cutler et al. (1989) identify a significant and positive correlation between stock returns and industrial production growth over the period 1926-1986. For the index of industrial production, the empirical results reveal a detrimental effect, since the coefficient is both negative and statistically significant. Nevertheless, this is still in line with previous literature, although the impact of industrial production on stock markets is ambiguous (Subeniotis et al., 2011).

Research investigation of stock market behavior has exposed a strong link between stock market prices and both market capitalization and the economic sentiment indicator (ESI). Researchers (Harvey, 1988; Chen, 1991; Estrella \& Hardouvelis, 1991; Estrella \&Mishkin, 1997; Moneta, 2003; Subeniotis et al., 2011) found a positive correlation between stock market return and the economic sentiment indicator, according to the results of their studies, while Baker and Wurgler (2006) note the importance of behavioral finance due to sentiments about future financial activities, and find that the part of the economic sentiment index that concerns investors is positively linked to stock markets. The results for the economic sentiment indicator also establish a positive link with stock market indices. Consumer and producer optimism or pessimism about the economy is a key determinant of stock market performance. If the market participants are confident regarding their future income levels, they will be more willing to invest in the stock market. Accordingly, businesses will increase production and inventory levels, since they will 
anticipate higher demand for their products, which in turn influences the stock market. The positive fluctuations in the market capitalization (\% of GDP) index reflect a positive relationship between market capitalization and stock market indices, which is consistent with both economic theory and previous literature. Since market capitalization is the product of stock prices multiplied by the number of stocks, it could be argued that this index rises when stock prices grow, as the number of stocks is a constant. Still, stock prices rise when investor demand increases, which leads to the conclusion that the demand for stocks is positively correlated with the market indices.

The Purchasing Managers Index (PMI) is widely used to assess and predict the activity of the economy and thus has an impact on financial markets, including the stock market. It is a leading indicator and can be used as an alternative to the Economic Sentiment Indicator or ZEW. This index measures the growth of economic activity in the manufacturing sector and indirectly the whole economy. The ZEW indicator is also a leading indicator, which in practice is used to evaluate the prospects of the German economy. A positive reading indicates a strengthening of the euro (Hufner, Schroder 2002). Studies by Hufner and Schroder (2002) show that these indicators have explanatory power if they are lagged by up to five months in relation to industrial production. The ZEW indicator is usually the first to be released and has a two-month lead over the PMI indicator. Out-of-sample forecast evaluations suggest that ZEW provides the best forecasts for industrial production compared to the PMI. The PMI is a very useful guide to economic growth, which is strongly correlated with the GDP of different countries. Meanwhile, the ZEW indicator does not correlate as well as the PMI but it has the advantage of being available three months ahead of the PMI data. This gives traders and investors greater warning about changes in the economic growth cycle and impact stock prices in advance.

The effect of the employment rate on the development of stock indices and their return has been widely investigated by various studies. Economists consider the employment rate as one of the economic indicators that helps in gaining better knowledge about the state of the economy. This indicator shows a country's ability to put its population to work and thereby generate income for its citizens. Stocks generally rise or fall with good or bad employment reports, as investors digest the potential changes in these areas (Singh et al., 2011). The investigations conducted by Boyd et al. (2005) showed the impact of an unanticipated unemployment rate on stock returns. The present investigations found that, on average, an announcement of rising unemployment is good news for stocks during economic expansions and bad news during economic contractions. Gonzalo and Taamouti (2017) suggested a reasonable explanation of the impact of the unemployment rate on stock market prices. With the help of the Fisher and Phillips curve equations, they have proven that a high unemployment rate is followed by monetary policy action of the Federal Reserve. When the unemployment rate is high, the Federal Reserve decreases the interest rate, which in turn increases stock market prices. The alternative indicator for the employment rate is the unemployment rate; Boyd et al. (2001) described the significance of the unemployment rate for stock returns.

Some investigations examined the relationship between public investments and stock market return. According to Belo and $\mathrm{Yu}$ (2012), if public sector capital increases 
the marginal productivity of private inputs, the model predicts a positive relationship between the public sector investment rate and the firm's risk premium, controlling for the private sector investment rate. Similarly, controlling for the public sector investment rate, the model predicts a negative relationship between the private sector investment rate and the company's risk premium. In addition to this, the positive correlation between corporate investment and the stock market can be improved. The traditional explanation for this relationship is that stock prices reflect the marginal product of capital (Baker et al., 2003). There are a number of ties between the stock market and corporate investment policy (Titman et al., 2010).

The literature review on the relationship between oil shocks and stock market activities has shown that changes in the price of crude oil are associated with the fluctuation of stock prices Recent papers by Hamilton (2009), Kilian (2009), and Kilian, Park (2009), among others, suggest that different price shocks in the crude oil market have distinct effects on the stock market, in the sense that the responses of aggregate stock returns differ depending on the cause of oil supply or demand shocks. Oil shocks have the highest impact on the energy sector, especially on the economies of such countries as Brazil, Russia, China and India. The economic impact on developing countries is generally more positive intense than the impact on industrialized countries. Since oil prices do not affect all the economic sectors, this indicator is not very significant when talking about the overall impact on stock market returns.

The researchers that have investigated the influence of changes in oil prices on stock market returns have determined that changes in oil prices are associated with the fluctuations of stock prices (Sadorsky, 1999; Hamilton, 2009; Killian, 2009; Kang \& Ratti, 2013). A positive oil-market specific demand shock (indicating greater concern about future oil supplies) significantly increases uncertainty in economic policy and reduces real stock returns (Kang \& Ratti, 2013). An unpredictable increase in policy uncertainty negatively affects the real stock returns in the United States. Shocks in oil price relative prices, redistribute income and influence expectations about inflation and the real interest rate. Daly and Fayyad (2011) studied seven different countries and found that the price of oil can forecast stock return better after the latest increase in oil prices. Using the DCV and VAR analysis they found that when oil prices rise sharply, this forecasts stock fluctuations in the United States, United Arab Emyrates and Kuwait but not in the United Kingdom, Oman, Bahrain and Qatar. It can be concluded that the relationship between higher oil prices and stock movements can be explained using cash flows and the discount rate. Bearing this in mind, higher production costs, interest rate and inflation are relevant factors. Structural oil price shocks have long-term consequences for economic policy uncertainty, and this provides an additional channel by means of which structural oil price shocks influence the stock market.

Along with oil price shocks, the authors examine the prices of gold and silver. An increase in the prices of gold and silver attracts investors to the commodity market, which might decrease investor preference towards the equity market. This indicates that a negative relationship is expected between gold and silver, and stock market returns (Patel 2012). According to Buyuksalvarci (2010), the price of gold does not appear to have any significant effect on stock markets. There is apparent evidence that in turbulent 
periods with economic uncertainty, as stock prices fall, the price of gold rises and the focus is on gold as a safe investment instrument.

The exchange rate can result in either a positive or a negative impact on stock returns. Ma and Kao (1990) suggested that for a country which dominates in exports currency depreciation is expected to have a positive impact on domestic stock market returns. Furthermore, Johnson and Soenen (1998) argued that a depreciation of the currency makes imports more costly and results in a higher domestic price level, which is expected to have a negative influence on stock market returns. This, however, does not correspond with the findings of Abdullah and Hayworth (1993), who find a positive relation between these two variables.

Frimpong (2009) discovered that all macroeconomic indicators, with the exception of the exchange rate, affect stock prices negatively. Aydemir and Demirhan (2009) determined that the exchange rate affects all stock market indices. Adebiyi et al. (2009) established a causal relationship from oil price shocks to stock returns, and from stock returns to the real exchange rate. Liu and Shrestha (2008) also found that a co-integrating relationship exists between stock prices and the exchange rate. Gunasekarage et al. (2004), and Adam and Tweneboah (2008) used national currency per United States dollar (USD) as a proxy for the exchange rate. As the exchange rate is the price of a currency in terms of another currency, it will affect net exports (Osamwonyi \& Evbayiro-Osagie, 2012). Vejzagic and Zarafat (2013) found that changes in exchange rates would have an impact on the firm's competitiveness as they affect the price of foreign currency, leading to changes in the firm's profits and equity, which in turn will lead to price adjustments in the stock market. Consequently, when stock prices rise, they will attract foreign capital and when prices fall, they will be less appealing to foreign investors, which will lead to a reduction in corporate wealth, and as a result, a reduction in the country's wealth (Vejzagic \& Zarafat, 2013; Barakat et al., 2016). Aurangzeb (2012) showed that the exchange rate has a positive impact on stock market performance. The exchange rate can result in either a positive or a negative impact on stock returns. Ma and Kao (1990) suggest that for an export-dominated country currency depreciation is expected to have a positive impact on domestic stock market returns. Moreover, Johnson and Soenen (1998) argue that a depreciation of the currency makes imports more costly and results in a higher domestic price level, which is expected to have a negative impact on stock market returns. This however, does not correspond with the findings of Abdullah and Hayworth (1993), who find a positive relation between these two variables.

The market size of pension funds is also an important indicator that influences stock market returns. Meng and Pfau (2010) found that pension fund financial assets have a positive impact on stock market depth and liquidity as well as on private bond market depth. Nevertheless, when they split the countries into two groups according to their level of financial development, the impact was only significant for countries with "high" financial development. Pension funds do not influence capital market development in countries with a "low" level of financial development. Because of the pension system reform, pension fund assets are growing rapidly and are increasingly providing a source of investment funds to their domestic financial markets. Pension fund investments are expected to increase the availability of long-term funds, enhance competition, 
induce financial innovation, and improve corporate governance. To the extent that such financial market improvements related to financial market size and activity, some studies confirm only to an extent the existence of positive impacts from pension funds on the development of stock markets and private bond markets (Raddatz \& Schmukler, 2008).

The authors of the paper also examined the market size of investment funds because mutual funds have played a very important role in stock market volatility. When mutual funds buy and sell stocks, the prices of those stocks are automatically affected. In fact, because of the size of their investments, mutual funds can have a huge impact on stock prices, in both the short and long term. Mutual fund trading can actively push stock prices up or down on any given day, and the herding effect of mutual funds and other large-scale institutional investors can create long-lasting trends that influence a stock's price over time. Oha and Parwada (2007) examined the association of mutual fund flows with stock market returns in Korea. The results showed a positive relationship between mutual fund flows and the stock market. Walter and Weber (2006) analyzed the aggregate flows of mutual funds and stock returns. The results of the study showed that stock returns are highly correlated with unexpected cash flow into the mutual funds. Based on the same pattern, Hsiehy et al. (2011) studied different stock markets in Asian emerging countries. The research findings revealed that the inflows of mutual funds are connected to positive stock returns and currency appreciation. It was also found that positive feedback affects the Asian stock markets. The primary focus must be on the crisis and how withdrawals of funds affect European and USA stock markets. Manconi et al. (2012) found that during the 20072008 crisis, fixed-income mutual funds transmitted the crisis from the securitized bond market to the corporate bond market. Open-end mutual funds had a significant impact on the transmission of the 2007-2008 crisis from financial stocks to non-financial stocks, resulting in very large temporary price discounts for many non-financial stocks. This evidence highlights that even non-leveraged financial intermediaries can play an important role in the propagation of financial instability and ensuring sustainability in the long term (Hau, Lau 2016).

Hedge, exchange-traded funds (ETF) and alternative funds have grown substantially in the last decade and their impact on stock market returns has increased. These funds make stock markets less risky and they lower stock market volatility in the short term, because they use more data based investment strategies and their analysts can find out more information about companies than the average investor can do. At the same time, due to the use of the same quantitative investment strategies, they have an impact on the risk increase in the long term, which in this situation can be mentioned as asset bubbles. Nevertheless, in terms of the long-term perspective, investment funds ensure an increase in stock market activity due to their size and capitalization. It can be concluded that mutual funds, as core subjects in the distribution of capital, affect stock markets. The bond fund effect on the equity market should also be the focus of attention.

An explanation can start with the fact that stocks tend to move in a direction different to that of bonds, so that the increased cost of country debt or a poorer country credit rating could influence stock prices (Jorion, Zhang, 2007). Most researchers have 
investigated the influence of changes in credit rating on the stock prices of publicly traded companies. The greatest part of them found evidence that rating downgrades generate a significantly larger impact than rating upgrades (Dichev \& Piotroski, 2001; Goh \& Ederington, 1999). Choy, Gray and Ragunathan (2006) studied the impact of Moody and S\&P rating revisions of 63 companies on the Australian stock market between 1989 and 2003. Their results showed a significant and negative impact for downgrades, and an insignificant impact for upgrades. According to them, companies disclose positive information very quickly and stock prices immediately reflect such information, anticipating rating changes. Servigny and Renault (2004) observed a negative reaction before the rating change date and stock prices fluctuations. This can be explained by the conservatism of the rating agencies, while after the change it can be explained by market under-reaction, possibly arising from a lower free cash flow to equity after a downgrade, which would increase the cost of funding the company and the time institutional investors may take to decide to divest a certain company's stock. The authors also investigated micro fundamental indicators that have an impact on stock market volatility: the average of market P/E, which could be treated as significant for further investigation.

In part, investment portfolio managers and researchers alike are well aware of the generally negative relation between the market $\mathrm{P} / \mathrm{E}$ ratio and stock returns (Weigand \& Irons 2007). The authors examine the relation between $\mathrm{P} / \mathrm{E}$ ratios and future returns using two measures of the market P/E ratio: the metric more popular among the investing public, using one-year trailing earnings (the $\mathrm{P} / \mathrm{E} 1$ ), and the metric favored by academicians, using ten-year smoothed earnings (the P/E10). Campbell and Shiller (2001) also showed that an unusually high market P/E ratio forecasts poor future stock returns, as it is stock prices, not earnings that account for most of the ratio's reversion to its historical mean. High-P/E periods are preceded by accelerating equity returns and declines in both nominal interest rates and stock market volatility. Following these periods, stock returns are marginally higher when the growth of earnings is strong and interest rates continue falling. In particular, high-P/E periods triggered by temporary earnings declines are followed by low positive stock returns, but returns are negative when earnings grow rapidly and the market $\mathrm{P} / \mathrm{E}$ climbs above 20. Following both types of high-P/E events, however, real stock returns are appreciably lower than average for the subsequent decade (Weigand \& Irons, 2006).

Drechsler (2011) found that earnings increases are a persistent phenomenon that can lead to higher share prices. The financial literature is replete with discussions of the relationship between company earnings and stock returns. Nevertheless, much of that literature is concerned primarily with earnings estimates and the effects that earnings surprises and revisions have on stock prices. Firms with an expected high growth of earnings tend to underperform on the market because it is difficult to meet the market's high expectations. Companies with low earnings expectations tend to do better than expected, realizing that the stock price already reflects the general consensus about future earnings.

There is extensive literature depicting the dynamics of sentiment by constructing theoretical models and analyzing the influences of sentiment dynamics on asset 
price fluctuation. The belief diffusion model established by Kirman (2005) according to the Markov chain and the mutual mimetic contagion model established by Lux (1995) with the help of the differential equation method described the evolution mechanism of herding sentiment. The static noise trading model devised by De Long et al. (1990), the dynamic noise trading model by Binswanger (1999), the static overconfidence and self-attribution model by Daniel et al. (1998), and the dynamic overconfidence and self-attribution model by Gervais and Odean (2001) described the evolution mechanism of private noise sentiment. The positive feedback model by De Long et al. (1990) and the behavior model by Westerhoff (2004), which reflected two basic psychological factors, fear and greed, in the market, portrayed the evolution mechanism of momentum sentiment. Although the famous Investors Intelligence Index was created in the 1950s and refined in the 1960s, it was not until the turn of the century that the index was put to a rigorous test. Market sentiment is generally characterized as bullish or bearish. Stock prices go down when bears are in control and go up when bulls are in control. The markets are driven by sentiment and market sentiment is not always synonymous with fundamental value. In other words, a market sentiment indicator could be determined as an indicator of feelings and emotions, whereas fundamental value is about business performance. Investors make money by finding stocks that are overvalued or undervalued based on market sentiment. Investors and traders use different indicators to measure market sentiment in order to determine the best stocks for trade. These indicators include: the 52 week High/Low Sentiment Ratio, the CBOE Volatility Index, Bullish Percentage, the 50-day moving average and the 200-day moving average. It can be concluded that economic sentiment indicators are more useful in forecasting shortterm market return fluctuations and are not significant in the long-term or for ensuring stock market return sustainability.

The Elliot Wave theory and Relative Strength Index (RSI) are indicators that are more suitable for taking investment decisions and they form a part of the technical analysis. The Relative Strength Index (RSI), developed by Wilder (1978), is one of the best-known and most widely used technical analysis indicators. The existence of a link between past developments and future evolutions has been shown in many studies (Malkiel, 1981; Sweeney 1988; Jegadeesh, 1990; Brock et al., 1992; Chopra et al.,1992; Gencay, 1997; Dempster \& Jones, 2001; Austin et al., 2004; Grant et al., 2005). The RSI is a commonly used oscillator in technical analysis because of its ease of use and interpretation. The RSI involves comparing the rise of closing prices with their decline within a certain period. In comparison with the classic form of the indicator, the RSI version proposed by Taran-Morosan (2011) generated a higher gain when using a different interpretation, even opposite of the classic one. Therefore, the study concludes that an analysis of the research results reveals that the extreme values of the RSI and RSIm do not indicate the return of a trend but rather the continuation of its direction, at least for the short term. The classic interpretation is of no use while the reversed interpretation gives positive results for both forms of the indicator. Anderson and $\mathrm{Li}$ (2015) contribute to the important debate on the profitability of technical analysis by focusing on one particular technical indicator: the Relative Strength Index (RSI). The authors proposed to use the RSI for short-term investors, because RSI had proven adept at identifying the potential turning points in stock prices changes. The Elliot Wave theory is frequently used in 
practice. It provides investors with more detailed information about the situation in stock markets, but it is not the most significant; it just can be used as a supplementary indicator for stock market analysis.

Following are insights that could be drawn with regard to all the analysed indicators. The authors have confirmed the importance of the GDP growth rate on stock market returns and the relationship between long-term stock market returns and longterm GDP growth. Additionally, increments in the federal funds rate have been found to have a significant negative effect on predicted stock returns in the short term, but a positive effect over a longer period. Most of the reviewed studies have shown that there is a connection between inflation and stock market return. The authors propose to examine the impact of the CPI on stock market return in combination with other macroeconomic, microeconomic and behaviour indicators. Research investigations revealed a strong link between stock market prices and both market capitalization and the economic sentiment indicator (ESI). Oil shocks have the highest impact on the energy sector and have the greatest influence on stocks from this sector. No significant effect of gold and silver prices on stock market return was discovered, apart from evidence that in turbulent periods involving economic uncertainty, as stock prices fall, the price of gold rises and the focus is on gold and silver as a safe investment instrument. Other important indicators for stock market volatility, such as the exchange rate, can result in either a positive or a negative impact on stock returns, but for a country dominated by exports, currency depreciation is expected to have a positive influence on domestic stock market returns. Some studies confirm the positive impact of pension funds on the development of stock markets and private bond markets, as well as the importance of mutual funds for stock markets. The investigations have shown the impact of the unemployment rate on stock returns by way of announcements of rising unemployment. Rising unemployment is a positive signal for stocks during economic expansions and a negative signal during economic contractions.

The authors of the present paper analyzed the differences between the ZEW and PMI indicators and concluded that the ZEW indicator provides the best forecasts for industrial production compared to the PMI, but at the same time the PMI indicator is used as a guide for economic growth, which strongly correlates with the GDP of different countries. The authors set apart the use of the P/E market indicator for further investigation.

Based on the investigations it can be concluded that economic sentiment indicators are more useful in forecasting short-term market return fluctuations and are not significant in the long term or for ensuring stock market return sustainability. Similarly, the use of the Elliot Wave theory can supported by defining this indicator as supplementary and more suitable for stock market selection but not as crucial for investment decisions. 


\section{THE SET OF IMPACT CRITERIA FOR STOCK MARKET SELECTION}

The authors of the present paper have investigated the indicators that have a positive, negative or both effects on stock market returns and have suggested the most reasonable set of impact criteria for stock market selection.

It has been proven that the most significant indicators with a positive impact on stock market returns are Real GDP, the 10-year government benchmark yields, the monetary policy rates, which can also be used as an alternative indicator for 10-year government benchmark yields, the market size of investment funds, the Purchasing Managers Indicator (PMI), market capitalization (\% of GDP) and the employment rate. Equally important are such indicators as the size of the pension funds market, the economic sentiment indicator (ESI) and the ZEW, due to their positive relation to stock market volatility. However, they are more significant in the short term.

In contrast, it was discerned that the gold price, silver price, the changes in oil prices, the country credit rating, the unemployment rate and the $\mathrm{P} / \mathrm{E}$ index ratio have a negative impact on stock market returns. The most significant indicators from this group are the unemployment rate and the P/E index ratio. As previously mentioned, oil shocks do not have an impact on all economic sectors. They have major influence only on the energy sector. Gold and silver could be used in order to protect investments in periods of economic crisis, but they do not have a significant impact on stock market returns in normal economic conditions.

It must be emphasized that some indicators have a dual role - they have both positive and negative effects on stock market volatility. These indicators are: the government debt level or, alternative to this indicator, the debt to GDP ratio, the exchange rate and inflation, with the Consumer Price Index as an alternative indicator. These three indicators have a significant impact on stock market returns. It must be noted that the effect of the government debt level is insignificant in the short term. Quite a few empirical studies have provided evidence that inflation has a negative short-term impact on stock returns, while other studies have reported a positive long-run Fisher effect on stock returns.

A detailed analysis revealed ten indicators for sustainable return that will make up the set for further market analysis: real GDP, 10-year government benchmark yields, Consumer Price Index, investment funds market size, debt to GDP ratio, unemployment rate, exchange rate (local currency per USD), Purchasing Managers Indicator (PMI), market capitalization (\% of GDP) and P/E index ratio (see Table 1).

The next level of investigation should be the formation of the optimal set of impact criteria for stock market return. With this purpose in mind, the authors will select experts from academic and business associations who will rank these indicators according to their significance for stock market return. The results will provide the direction for further research. 
Table 1: The positive or negative influence of impact indicators on stock market return and identification of sustainable indicators

\begin{tabular}{|c|c|c|c|}
\hline \multirow{2}{*}{ Indicator } & \multicolumn{2}{|c|}{ Influence on stock market return } & \multirow{2}{*}{ Sustainable } \\
\hline & Positive & Negative & \\
\hline Real GDP, \% yoy & + & & + \\
\hline $\begin{array}{l}\text { 10-year government benchmark yields, \% (the } \\
\text { alternative - monetary policy rates) }\end{array}$ & + & & + \\
\hline Consumer Price Index & + & + & + \\
\hline Inflation & + & + & \\
\hline Gold price & & + & \\
\hline Silver price & & + & \\
\hline Oil prices & & + & \\
\hline Pension funds market size & + & & \\
\hline Investment funds market size & + & & + \\
\hline Country credit rating & & + & \\
\hline Government debt level (debt to GDP ratio) & + & + & + \\
\hline Employment rate & + & & \\
\hline Unemployment rate & & + & + \\
\hline Exchange rate & + & + & + \\
\hline Economic Sentiment Indicator (ESI) & + & & \\
\hline Purchasing Managers Indicator (PMI) & + & & + \\
\hline ZEW & + & & \\
\hline Market capitalization (\% of GDP) & + & & + \\
\hline P/E index ratio & & + & + \\
\hline
\end{tabular}

Note: created by the authors, based on the investigated research studies

\section{CONCLUSION}

A detailed analysis has been conducted of the impact indicators that have an influence on stock market return. The analysis of the selected topic showed that there is no unified and general set of indicators that could be used for detailed stock market selection.

Among the analyzed impact indicators the authors distinguished those that have a positive, negative or dual influence on stock market returns:

- Positive impact: real GDP, 10-year government benchmark yields, monetary policy rates that can be used as an alternative indicator for 10-year government benchmark yields, inflation and the Consumer Price Index as its alternative indicator, investment funds market size, Purchasing Managers Indicator (PMI), market capitalization (\% of GDP), employment rate, pension funds market size, Economic Sentiment Indicator (ESI) and the ZEW (Fama, 1990; Schwert, 1990; Mohammad et al.,2009; Hussain et al.,2001; Kuttner, 2005; Masuduzzaman, 2012; Ullah et al., 2014; Talla, 2013; Cutler et al., 1989; Harvey, 1988; Chen, 1991; Estrella \& Hardouvelis, 1991; Estrella \& Mishkin, 1997; Moneta, 2003; Subeniotis et al., 2011 and et al.). 
- Negative impact: gold price, silver price, oil price, country credit rating, unemployment rate and P/E index ratio (Patelis, 1997; Al-Sharkas, 2004; Akkum \& Vuran, 2003; Maysami \& Koh, 2000; Papapetrou, 2001; Tursoy et al., 2008; Uddin \& Alam, 2007; Ullah et al., 2014; Flannery \& Protopapadakis, 2002; Thalassinos et al., 2006; Servigny \& Renault, 2004 and et al.).

- Dual impact: government debt level or, alternative to this indicator, debt to GDP ratio, exchange rate and inflation, or the Consumer Price Index as its alternative indicator. The positive effect of these indicators is observable in the long term and is negative in the short term.

There is a critical need on the stock market for further investigation and experts should be invited to finally define the set of impact criteria for stock markets. A set of impact indicators with the highest influence on stock market returns was proposed and defined: real GDP (\%, yoy), exchange rates, Consumer Price Index, 10 -year government benchmark yields (\%), Purchasing Managers Index (PMI), market capitalization (\% of GDP), debt to GDP ratio, employment rate, P/E index ratio and market size of investment funds. This set of impact criteria will be used for further and more detailed stock market selection.

Based on the researches review on the influence of impact indicators on stock markets (chapter 2), the authors of the present paper have investigated the indicators, which have positive, negative or both effects on stock market returns and suggested the most reasonable set of impact criteria for stock market selection.

\section{REFFERENCES:}

1. Abdullah, A. D., Hayworth S. C. (1993), Macroeconometrics of Stock Price Fluctuations, Quarterly Journal of Business and Economics, 32 (1): 50-67.

2. Adam, A. M., Tweneboah, G. (2008), Macroeconomic Factors and Stock Market Movement: Evidence from Ghana. Munich Personal RePEc Archive 11256, 1-16. https://doi.org/10.2139/ssrn.1289842

3. Adebiyi, M.A., Adenuga, A.O., Abeng, M.O., Omanukwue, P.N. (2009), Oil Price Shocks, Exchange Rate and Stock Market Behaviour: Empirical Evidence from Nigeria. Source:https://www.researchgate.net/publication/241306346_Oil_Price_ Shocks_Exchange_Rate_and_Stock_Market_Behaviour_Empirical_Evidence_ from_Nigeria (accessed: 15 ${ }^{\text {th }}$ August 2017)

4. Adrangi, B., Chatrath, A., Sanvicente, A. (2002), Inflation, Output, and Stock Prices: Evidence From Brazil, The Journal of Applied Business Research, 18 (1): 61-77.

5. Adrianaivo, M., Yartey, C. A. (2009), Understanding the Growth of African Financial Markets. IMF Working Paper WP/09/182.

6. Aigheyisi, S. O., Edore, J. O. (2013), Foreign Financial Resources Inflows and Stock Market Development, Research Journal of Finance and Accounting, 4(9): 43-49. 
7. Akkum, T., Vuran, B. (2003), Analysis of the Macroeconomic Factors Affecting Stock Returns in Turkish Stock Market with Arbitrage Pricing Model, Istanbul Chamber of Certified Public Accountants Financial Fiscal Solution Journal 65: $1-14$.

8. Alam, M., Uddin, G. S. (2009), Relationship between Interest Rate and Stock Price: Empirical Evidence from Developed and Developing Countries, International Journal of Business and Management, 4(3): 43-51. https://doi.org/10.5539/ijbm. v4n $3 \mathrm{p} 43$

9. Albeni, M., Demir, Y. (2005), Impact of Macroeconomic Factors on Financial Sector Stock Prices (ISE Application), Muğla University SBE Journal, 14: 1-18.

10. Al-Sharkas, A. (2004), The Dynamic Relationship between Macroeconomic Factors and the Jordanian Stock Market, International Journal of Applied Econometrics and Quantitative Studies, 1(1): 97-114.

11. Ang, A., Bekaert, G. (2001), Stock return predictability: Is it there? National Bureau of Economic Research. Working Paper No. 8207.

12. Austin, M., Bates, G., Dempster, M., Leemans, V., Wiliams, S. (2004), Adaptive systems for foreign exchange trading, Quantitative Finance, 4(4): 37-45. https://doi. org/10.1080/14697680400008593

13. Aydemir, O., \& Demirhan, E. (2009), The relationship between stock prices and exchange rates: Evidence from Turkey, International Research Journal of Finance and Economics, 23: 207-215.

14. Baker, M., Wurgler, J., (2006), Investor Sentiment and the Cross-Section of Stock Returns, Journal of Finance, 61(4): 1645-1680. https://doi.org/10.1111/j.15406261.2006.00885.x

15. Baker, M., Stein, J., Wurgler, J. (2003), When does the market matter? Stock prices and the investment of equity-dependent firms, Quarterly Journal of Economics 118: 969-1006. https://doi.org/10.1162/00335530360698478

16. Barakat, M. R., Elgazzar, S. H., Hanafy, K.M. (2016), Impact of Macroeconomic Variables on Stock Markets: Evidence from Emerging Markets, International Journal of Economics and Finance, 8(1): 195-207. https://doi.org/10.5539/ijef.v8n1p195

17. Belo, F., Yu, J. (2012), Government Investment and the Stock Market. Source: https:// ssrn.com/abstract=1508120.https://dx.doi.org/10.2139/ssrn.1508120

18. Bernanke, B.S., Kuttner, K. N. (2005), What Explains the Stock Market's Reaction to Federal Reserve Policy?, The Journal of Finance, 60(3): 1221-1257. https://doi. org/10.1111/j.1540-6261.2005.00760.x

19. Binswanger, M. (1999), Stock Markets, Speculative Bubbles and Economic Growth. Edward Elgar, Aldershot.

20. Bodie, Z. (1976), Common stocks as a hedge against inflation. Journal of Finance, 3:459-470. https://doi.org/10.1111/j.1540-6261.1976.tb01899.x 
21. Boyd, J. H., Jaganathan, R., Hu, J. (2001), The stock market's reaction to unemployment news: Why bad news is usually good for stock. National Bureau of Economic Research, Working Paper No. 8092. https://doi.org/10.3386/w8092

22. Boyd, J. H., Hu, J., Jagannathan, R. (2005), The stock market's reaction to unemployment news: Why bad news is usually good for stocks, Journal of Finance 60(2): 649-672. https://doi.org/10.1111/j.1540-6261.2005.00742.x

23. Brock, W., Lakonishok, J., LeBaron, B. (1992), Simple technical trading rules and the stochastic properties of stock returns, Journal of Finance, 47(5): 1731-1764. https://doi.org/10.1111/j.1540-6261.1992.tb04681.x

24. Broyer, S., Savry, G. (2002), German leading indicators: Which one should be monitored? CDC IXIS Capital Markets Flash no. 2002-38.

25. Buyuksalvarci, A. (2010), The effects of macroeconomic variables on stock returns: Evidence from Turkey, European Journal of Social Sciences, 14(3): 404-416.

26. Cagli, U., Halac, U., Taskin, D. (2010), Testing Long-Run Relationship between Stock Market and Macroeconomic Variables in the Presence of Structural Breaks: The Turkish Case, International Research Journal of Finance and Economics 48: 49-60.

27. Campbell, J. Y. (1987), Stock returns and the term structure, Journal of Financial Economics, 18: 373- 399. https://doi.org/10.1016/0304-405X(87)90045-6

28. 'Campbell, J.Y., Shiller, R. J. (2001), Valuation Ratios and the Long-Run Stock Market Outlook: an Update, Cowls Foundation Discussion Paper 1295, Yale University. March 2001.

29. Chen, N., Roll, R., Ross. S. (1986), Economic Forces and the Stock Market, The Journal of Business, 59(3): 383-403. https://doi.org/10.1086/296344

30. Chen, N. (1991), Financial Investment Opportunities and the Macroeconomy. Journal of Finance, 46(2): 529-554. https://doi.org/10.1111/j.1540-6261.1991.tb02673.x

31. Chopra, N., Lakonishok, J., Ritter, J. (1992), Performance measurement methodology and the question of whether the stocks overreact, Journal of Financial Economics, 31: 235-268. https://doi.org/10.1016/0304-405X(92)90005-I

32. Choy, E. Y. W., Gray, S. F., Ragunathan, V. (2006), Effect of credit rating changes on Australian stock returns, Accounting and Finance, 46(5): 755-769. https://doi. org/10.1111/j.1467-629X.2006.00192.X

33. Cohn, A., Lessard, D. (1980), The Effect of Inflation on Stock Prices: International Evidence, The Journal of Finance, 36(2): 277-286. https://doi. org/10.1111/j.1540-6261.1981.tb00440.x

34. Coleman, A. K., Agyire-Tettey, K. F. (2008), Impact of macroeconomic indicators on stock market performance: The case of the Ghana Stock Exchange. The Journal of Risk Finance, 9(4): 365-378. https://doi.org/10.1108/15265940810895025 
35. Cutler, D., Poterba, J., Summers, L. (1989,What moves stock prices, Journal of Portfolio Management, 15: 4-12. https://doi.org/10.3905/jpm.1989.409212

36. Daly, K., Fayyad, A. (2011), The impact of oil price shocks on stock market returns: Comparing GCC countries with the UK and USA, Emerging Markets Review, 12(1): 61-78. https://doi.org/10.1016/j.ememar.2010.12.001

37. Daniel, K., Hirshleifer, D., \& Subrahmanyam, A. (1998), Investor Psychology and Security Market Under- and Overreactions, The Journal of Finance, 53(6): 18391885. https://doi.org/10.1111/0022-1082.00077

38. De Long, J. B., Shleifer, A. M., Summers, L. H., Waldmann, R. J. (1990), Noise trader risk in financial markets, Journal of Political Economy, 98 (August): 703-738. https://doi.org/10.1086/261703

39. Dempster, M., Jones, C. (2001), A real-time adaptive trading system using genetic programming, Quantitative Finance, 1(4): 397-413. https://doi.org/10.1088/1469$7688 / 1 / 4 / 301$

40. Diaz, A., Jareno, F. (2009), Explanatory factors of the inflation news impact on stock returns by sector: the Spanish case, Research in International Business and Finance, 23(3): 349-368. https://doi.org/10.1016/j.ribaf.2008.12.001

41. Dichev, I. D., Piotroski, J. D. (2001), The long-run stock returns following bond ratings changes, Journal of Finance, 56(1): 173-203. https://doi.org/10.1111/00221082.00322

42. Dimson, E., Marsh, P., Staunton, M., Wilmot, J. (2016), Credit Suisse Global Investment Returns Yearbook 2016. Source: http://pangeafamilyoffices.com/getattachment/886b62bd-2fcf-4d76-af0e-1bcccb893ddb/2016\%20Credit\%20Suisse $\% 20$ Global\%20Investment\%20Returns.aspx

43. Drechsler, F.S. (2011), Yes, earnings do drive stock prices. Source: http://www.turnerinvestments.com/index.cfm/fuseaction/documents.detail/CID/3313

44. El-Nadar, H. N., Alraimony, A. D. (2013), The Macroeconomic Determinants of Stock Market Development in Jordan, International Journal of Economics and Finance, 5(6): 91-103. https://doi.org/10.5539/ijef.v5n6p91

45. Estrella, A., \& Hardouvelis, G. A. (1991), The Term Structure as a Predictor of Real Economic Activity, Journal of Finance, 46(2): 555-576. https://doi. org/10.1111/j.1540-6261.1991.tb02674.x

46. Estrella, A., Mishkin, F. (1997), The term structure of interest rates and its role in monetary policy for the European Central Bank, European Economic Review, 41: 1375-401. https://doi.org/10.1016/S0014-2921(96)00050-5

47. Fama, E.F. (1990), Stock returns, expected returns and real activity, Journal of Finance, 45: 1089-1108. https://doi.org/10.1111/j.1540-6261.1990.tb02428.x

48. Fama, E. F. (1981), Stock returns, real activity, inflation and money, American Economic Review, 71: 545- 565. 
49. Fama, E. F., French, K. (1989), Business conditions and expected returns on stocks and bonds, Journal of Financial Economics, 25: 23-49. https://doi.org/10.1016/0304405X(89)90095-0

50. Fama, E. F., Schwert, G. W. (1977), Asset returns and inflation, Journal of Financial Economics, 5: 115-146. https://doi.org/10.1016/0304-405X(77)90014-9

51. Firth, M. (1979), The Relationship between Stock Market Returns and Rates of Inflation, The Journal of Finance, 53(6): 743-749. https://doi.org/10.1111/j.1540-6261.1979. tb02139.x

52. Flannery, M. J., Protopapadakis, A. A. (2002), Macroeconomic factors do influence aggregate stock returns, The Review of Financial Studies, 15(3): 751-782. https://doi. org/10.1093/rfs/15.3.751

53. Frimpong, J. M. (2009), Economic forces and the stock market in a developing economy: Cointegration evidence from Ghana, European Journal of Economics, Finance and Administrative Sciences, 16: 1450-2275.

54. Garcia, V. F., Liu, L. (1999), Macroeconomic Determinants of Stock Market Development, Journal of Applied Economics, 2(1): 29-59.

55. Gencay R. (1998), Optimization of technical trading strategies and the profitability in security markets, Economics Letters, 59(2): 249-254. https://doi.org/10.1016/ S0165-1765(98)00051-2

56. Gervais, S., Odean, T. (2001), Learning to be Overconfident, The Review of Financial Studies, 14(1): 1-27. https://doi.org/10.1093/rfs/14.1.1

57. Goh, J. C. Y., Ederington, L. H. (1999), Cross sectional variation of the effect of bond rating changes on stock prices, The Quarterly Review of Economics and Finance, 39(1): 101-112. https://doi.org/10.1016/S1062-9769(99)80006-4

58. Gonzalo, J., Taamouti, A. (2017), The Reaction of Stock Market Returns to Unemployment. UC3M Working papers, 17-02: 1-32. https://doi.org/10.1515/snde-2015-0078

59. Grant, J., Wolf, A., Yu, S. (2005), Intraday price reversals in the US stock index futures market: a 15-year study, Journal of Banking Finance, 29(5): 1311-1327. https:// doi.org/10.1016/j.jbankfin.2004.04.006

60. Gultekin, N. (1983), Stock Market Returns and Inflation: Evidence from Other Countries, The Journal of Finance, 38 (1): 49-65. https://doi.org/10.1111/j.1540-6261.1983. tb03625.x

61. Gunasekarage, G., Pisedtasalasai, A., \& Power, D.M. (2004). Macroeconomic Influence on the Stock Market: Evidence from an Emerging Market in South Asia. Journal of Emerging Market Finance, 3(3), 285-304. https://doi. org/10.1177/097265270400300304

62. Hamilton, J. D. (2009), Causes and consequences of the oil shock of 2007-08. Brookings Papers on Economic Activity, Spring, 215-261. https://doi.org/10.1353/ eca.0.0047 
63. Harwey, C. R. (1988), The Real Term Structure and Consumption Growth, Journal of Financial Economics, 22(1988): 305-333. https://doi.org/10.1016/0304405X(88)90073-6

64. Hau, H., Lau, S. (2016), The Role of Equity Funds in the Financial Crisis Propagation, Review of Finance, 21(1): 77-108. https://doi.org/10.1093/rof/rfw023

65. Hsiehy, M.F., Yangz, T.Y., Yangx, Y.T., Lee, J.S. (2011), Evidence of Herding and Positive Feedback Trading for Mutual Funds in Emerging Asian Countries. Quantitative Finance, 11(3): 423-435. https://doi.org/10.1080/14697688.2010.506882

66. Horobet, A., Dumitrescu, S. (2009), On the causal relationships between monetary, financial and real macroeconomic variables: evidence from Central and Eastern Europe. Source: http://www.ecocyb.ase.ro/articles\%203.2009/Alexandra\%20Horobat.pdf (accessed: 10th September 2017)

67. Hüfner, F. P., Schröder, M. (2002), Forecasting Economic Activity in Germany How Useful are Sentiment Indicators?. ZEW - Center for European Economic Research. https://doi.org/10.2139/ssrn.339141

68. Ifionu, E. P., Ibe, R. C. (2015), Inflation, Interest Rate, Real Gross Domestic Product and Stock Prices on the Nigerian Stock Exchange: A Post SAP Impact Analysis, Research Journal of Finance and Accounting, 6(14): 215-223.

69. Jaffe, J., Mandelker, G. (1976), The 'Fisher Effect' for risky assets: An empirical investigation, Journal of Finance, 31: 447-458.

70. Johnson, R., Soenen, L. (1998), Stock Price and Exchange Rate: Empirical Evidence from the Pacific Basin, Journal of Asian Business 14: 1-18.

71. Jorion, P., \& Zhang, G. (2007), Information effects of bond rating changes: the role of the rating prior to the announcement, Journal of Fixed Income, 16(4): 45-59. https://doi.org/10.3905/jfi.2007.683317

72. Kalyanaraman, L., Tuwajri, B. (2014), Macroeconomic Forces and Stock Prices: Some Empirical Evidence from Saudi Arabia, International Journal of Financial Research, 5(1): 81-92. https://doi.org/10.5430/ijfr.v5n1p81

73. Kang, W., Ratti, R. A. (2013), Structural oil price shocks and policy uncertainty, Economic Modelling, 35: 314-319. https://doi.org/10.1016/j.econmod.2013.07.025

74. Kaul, G. (1986), Stock Returns and Inflation: The Role of the Monetary Sector. Working Paper, 1-37.

75. Kargi, N., Terzi, H. (1999), Analysis of the Causality between ISE, Inflation, Interest Rate and Real Sector in Turkey with VAR, ISE Journal, 4: 1-10.

76. Kemboi, J. K. \& Tarus, D. K. (2012). Macroeconomic Determinants of Stock Market Development in Emerging Markets: Evidence from Kenya. Research Journal of Finance and Accounting, 3(5), 57-68. 
77. Kilian, L. (2009), Not all oil price shocks are alike: Disentangling demand and supply shocks in the crude oil market, American Economic Review, 99: 1053-1069. https://doi.org/10.1257/aer.99.3.1053

78. Kirman, A. (2005), Testing for bubbles and change-points. Journal of Economic Dynamics and Control, 29(4): 765-799. https://doi.org/10.1016/j.jedc.2004.01.005

79. Liu, M.H., Shrestha, K. M. (2008). Analysis of the long-term relationship between macro-economic variables and the Chinese stock market using heteroscedastic cointegration, Managerial Finance 34 (11): 744-755. https://doi. org/10.1108/03074350810900479

80. Lux, T. (1995), Herd Behaviour, Bubbles and Crashes, Economic Journal, 105(431): 881-896. https://doi.org/10.2307/2235156

81. Ma, C. K., Kao, G. W. (1990), On Exchange rate Changes and Stock Price Reactions, Journal of Business Finance and Accounting, 11: 441-449. https://doi. $\operatorname{org} / 10.1111 / \mathrm{j} .1468-5957.1990 . t b 01196 . x$

82. Masuduzzaman, M. (2012), Impact of the Macroeconomic Variables on the Stock Market Returns: The Case of Germany and the United Kingdom, Global Journal of Management and Business Research, 12 (16): 23-34.

83. Malkiel B. (1981), A random walk down Wall Street. Norton. New York.

84. Manconi, A., Massa, M., Yasuda, A. (2012), The role of institutional investors in propagating the crisis of 2007-2008, Journal of Financial Economics, 104: 491-518. https://doi.org/10.1016/j.jfineco.2011.05.011

85. Maysami, R. C., Koh, T. S. (2000), A vector error correction model of the Singapore stock market, International Review of Economics and Finance, 9: 79-96. https://doi. org/10.1016/S1059-0560(99)00042-8

86. Meng, C., Pfau, W. D. (2010), The Role of Pension Funds in Capital Market Development, GRIPS Discussion Paper, 10(17): 1-20.

87. Mohammad, S. D., Hussain, A., Jalil, M. A., Ali, A. (2009). Impact of Macroeconomics Variables on Stock Prices: Empirical Evidence in Case of KSE (Karachi Stock Exchange), European Journal of Scientific Research, 38(1): 96-103.

88. Moneta, F. (2003), Does the yield spread predict recessions in the euro area?, European central bank working paper series, 294: 1-58.

89. Mutan, O., Canakci, E. (2007), Effects of Macroeconomic Factors on Stock Markets, Research Report of Share Market, 1-36.

90. Nelson, C. R., Kim, M. J. (1993), Predictable stock returns: The role of small sample bias, Journal of Finance, 48: 641-661. https://doi.org/10.1111/j.1540-6261.1993. tb04731.x

91. Oha, N. Y., Parwada, J. T. (2007), Relations between Mutual Funds Flows and Stock Market Returns in Korea, International Financial Markets, Institutions and Money, 17: 140-151. https://doi.org/10.1016/j.intfin.2005.10.001 
92. Osamwonyi I. O., Evbayiro-Osagie, E. I. E. (2012), The Relationship between Macroeconomic Variables and Stock Market Index in Nigeria, Journal of Economics, 3(1): 55-63.

93. Papapetrou, E. (2001), Oil Price Shocks, Stock Market, Economic Activity and Employment in Greece, Energy Economics, 23: 511-532. https://doi.org/10.1016/S01409883(01)00078-0

94. Patel, S. (2012), The effect of Macroeconomic Determinants on the Performance of the Indian Stock Market. Source: http://www.nmims.edu/NMIMSmanagementreview/pdf/august-2012/06-effect-macroeco-performance-indian-stock-market.pdf (accessed: 7th September 2017)

95. Patelis, A. D. (1997), Stock Return Predictability and the Role of Monetary Policy. The Journal of Finance, 52(5): 1951-1972. https://doi.org/10.1111/j.1540-6261.1997. tb02747.x

96. Raddatz, C., Schmukler, S. L. (2008), Pension Funds and Capital Market Development: How Much Bang for the Buck?, Policy Research Working Paper, 4787. Washington, DC: World Bank. Source: https://openknowledge.worldbank.org/handle/10986/6308 (accessed: 7th August 2017) https://doi.org/10.1596/1813-94504787

97. Ray, S. (2012), Testing Granger Causal Relationship between Macroeconomic Variables and Stock Price Behaviour: Evidence from India, Advances in Applied Economics and Finance, 3(1): 470-481.

98. Schwert, G.W. (1990), Stock Returns and Real Activity: a Century of Evidence, The Journal of Finance, 45(4): 1237-1257. https://doi.org/10.1111/j.1540-6261.1990. tb02434.x

99. Scott, A.O, \& Ovuefeyen, J.E. (2014). Do Government Expenditure and Debt Affect Stock Market Development in Nigeria? An Empirical Investigation, Research Journal of Finance and Accounting, 5(20): 1-11.

100. Servigny, A., Renault, O. (2004), Measuring and managing credit risk. New York, USA: McGraw Hill. 466 p.

101. Shanken, J., Weinstein, M. I. (2006), Economic forces and the stock market revisited, Journal of Empirical Finance, 13: 129-144. https://doi.org/10.1016/j.jempfin.2005.09.001

102. Singh, T., Mehta, S., Varsha, M. S. (2011), Macroeconomic factors and stock returns: Evidence from Taiwan, Journal of Economics and International Finance, 2(4): 217-227.

103. Subeniotis, D.N., Tampakoudis, I.A., Kroustalis, I.G., Poulios, M. (2011), Empirical Examination of Wealth Effect of Mergers and Acquisitions: The U.S. Economy in Perspective, Journal of Financial Management and Analysis, 24 (2): 30-38.

104. Sweeney, R. (1988), Some new filter rule tests: methods and results, Journal of Financial Quantity Analysis, 23(3): 285-300. https://doi.org/10.2307/2331068 
105. Talla, T. J. (2013), Impact of Macroeconomic Variables on the Stock Market Prices of the Stockholm Stock Exchange (OMXS30). Source: http://www.diva-portal.org/ smash/get/diva2:630705/FULLTEXT02.pdf (accessed: 10th September 2017)

106. Taran-Morosan, A. (2011), The relative strength index revisited, African Journal of Business Management, 5(14): 5855-5862.

107. Thalassinos, E., Kyriazidis, T., Thalassinos, J. (2006), The Greek Capital Market: Caught in Between Poor Corporate Governance and Market Inefficiency, European Research Studies Journal, 9(1-2): 3-24.

108. Timmermann A., \& Granger, C. (2004), Efficient market hypothesis and forecasting, International Journal of Forecast, 20(1): 15-27. https://doi.org/10.1016/S01692070(03)00012-8

109. Titman, S., Wei, K.C., Xie, F. (2010), Access to Equity Markets, Corporate Investments and Stock Returns: International Evidence. Source: http://www.fin.ntu. edu.tw/ conference/conference2010/proceedings/proceeding/4/4-3(A162).pdf (accessed: 7th August 2017) https://doi.org/10.2139/ssrn.1571648

110. Sadorsky, P. (1999), Oil price shocks and stock market activity, Energy Economics, 21: 449-469. https://doi.org/10.1016/S0140-9883(99)00020-1

111. Tursoy, T., Gursoy, N., Rjoub, H. (2008), Macroeconomic Factors, the APT and the Istanbul Stock Market, International Research Journal of Finance and Economics, 22: 49-57.

112. Uddin, M. G. S., Alam, M. M. (2007), The Impacts of Interest Rate on Stock Market: Empirical Evidence from Dhaka Stock Exchangel, South Asian Journal of Management and Sciences, 1(2): 123-132.

113. Ullah, F., Hussain, I., Rauf, A. (2014), Impacts of Macroeconomy on Stock Market: Evidence from Pakistan. International Journal of Management and Sustainability, 3(3): 140-146.

114. Vejzagic, M., Zarafat, H. (2013). Relationship between macroeconomic variables and stock market index: Co-integration evidence from FTSE Bursa Malaysia Hijrah Shariah index, Asian Journal of Management Sciences and Education, 2(4): 94-108.

115. Walter, A., Weber, F. M. (2006), Herding in the German Mutual Funds Industry, European Financial Management, 12(3): 375-406. https://doi.org/10.1111/j.13547798.2006.00325.x

116. Walter, J. R. (1988), How to Interpret the Weekly Federal Reserve Data. The Financial Analyst's Handbook, 2nd. ed. Illinois: Dow Jones-Irwin.

117. Weigand, R.A., \& Irons, R. (2007). The market P/E ratio, earnings trends, and stock return forecasts, The Journal of Portfolio Management, 87-101. https:/doi. org/10.3905/jpm.2007.690610 
118. Weigand, R.A., Irons, R. (2006), Does the Market P/E Ratio Revert Back to "Average"? Investment Management and Financial Innovations, 3(3): 30-39.

119. Westerhoff, F. (2004), Multi asset market dynamics, Macroeconomic Dynamics, 8: 596-616.

120. Wilder, W. J. (1978), New concepts in technical trading systems, Trend research. Greensboro. 118 p.

121. Yartey, C. A. (2008), The Determinant of Stock Market Development in Emerging Economies: Is South Africa Different? IMF Working Paper, WP/08/32. 


\title{
POKAZATELJI UTJECAJA NA PRINOSE NA TRŽIŠTU DIONICA
}

\author{
Alina Kvietkauskiene $\dot{3}^{3}$ \& Modestas Plakys ${ }^{4}$
}

\section{Sažetak}

Rad istražuje kako pokazatelji utjecaja utječu na prinose na tržištu dionica. Autori analiziraju različite teorijske i empirijske studije kako bi se stvorio skup kriterija za odabir na tržištu dionica. Cilj različitih istraživanja bio je da se utvrdi kointegrirajući odnos između prinosa na tržištu dionica i pokazatelja kao što su ponuda novca, devizni tečaj, kratkoročne i dugoročne kamate i drugo. Često se uočava kako cijene dionica fluktuiraju s ekonomskim pokazateljima koji imaju pozitivan ili negativan učinak na prinose na tržištu dionica. Detaljna analiza odabrane teme pokazala je da ne postoji opća ili jedinstvena metoda za odabir spomenutih kriterija. Stoga autori predlažu skup kriterija koji bi se trebali koristiti u odabiru na tržištu dionica kako bi se generirali dugoročno održivi prinosi.

Ključne riječi: pokazatelji utjecaja, prinos na tržištu dionica, odabir na tržištu.

\section{JEL klasifikacija: $G 1$}

\footnotetext{
3 Dr. sc. Alina Kvietkauskienè, predavač, Fakultet za poslovno upravljanjke, Tehničko sveučilište Gediminas u Vilniusu, Litva, E-mail: alina.kvietkauskiene@vgtu.lt

4 Modestas Plakys, dr. ekonomije, voditeljica Odjela za privatno bankarstvo, Nordea Bank AB, Vilnius, Litva, E-mail: modestas.plakys@nordea.com
} 